\title{
Development of system decision support tools for behavioral trends monitoring of machinery maintenance in a competitive environment
}

\author{
Michael Kanisuru Adeyeri ${ }^{1} \cdot$ Khumbulani Mpofu $^{1}$
}

Received: 5 December 2014/Accepted: 4 January 2017/Published online: 17 January 2017

(C) The Author(s) 2017. This article is published with open access at Springerlink.com

\begin{abstract}
The article is centred on software system development for manufacturing company that produces polyethylene bags using mostly conventional machines in a competitive world where each business enterprise desires to stand tall. This is meant to assist in gaining market shares, taking maintenance and production decisions by the dynamism and flexibilities embedded in the package as customers' demand varies under the duress of meeting the set goals. The production and machine condition monitoring software (PMCMS) is programmed in $\mathrm{C \#}$ and designed in such a way to support hardware integration, real-time machine conditions monitoring, which is based on condition maintenance approach, maintenance decision suggestions and suitable production strategies as the demand for products keeps changing in a highly competitive environment. PMCMS works with an embedded device which feeds it with data from the various machines being monitored at the workstation, and the data are read at the base station through transmission via a wireless transceiver and stored in a database. A case study was used in the implementation of the developed system, and the results show that it can monitor the machine's health condition effectively by displaying machines' health status, gives repair suggestions to probable faults, decides strategy for both production methods and maintenance, and, thus, can enhance maintenance performance obviously.
\end{abstract}

Michael Kanisuru Adeyeri

adeyerimichaeltut@gmail.com

Khumbulani Mpofu

mpofuk@tut.ac.za

1 Department of Industrial Engineering, Tshwane University of Technology, Pretoria, South Africa
Keywords Production strategies · Machine monitoring · Maintenance $\cdot$ Decision tools

\section{Introduction}

Liliane et al. (2006) opined that industrial manufacturing systems are characterised by continuous breakdowns with significant effect on profitability of business enterprise. These breakdowns which are critical to business success led to expensive equipment being idled, incurring of losses due to non-optimisation of labour, ratio of fixed cost to product output being negatively affected and nonconformance of output product quality as against the set standard. For manufacturing industries to have competitive advantage over others, there is need for such industries to understand the potentials of manufacturing and maintenance. If understood, proper strategy to exploit such potentials is highly needed. Strategy calls for the application of senses in adopting an approach in the right direction and at the right time. It is bound by integrity, goal and provision of guidance in decision-making for achievement of objectives (Liliane et al. 2006; Adeyeri and Kareem 2012).

Alhad et al. (2008) made known that the production system, sometimes, is void of satisfactory overall availability because of downtime initiated by non-conformance to set quality standards or excessive machine/component failures. Initial single station's mean-time-to-failure (MTTF) and mean-time-to-repair (MTTR) assessment could not ascertain the overall system performance, and dynamic resourcing and customers' satisfaction were not addressed in old total productive maintenance (TPM) and manufacturing execution systems (MES).

Researchers and industrialists have adopted simulation and optimization as veritable tools to evaluate the 
performance of manufacturing systems (Ólafsson and Kim 2002). However, a simple evaluation does not provide enough details for optimal decision-making.

The works of Papakostas et al. (2010) and Oke and Charles-Owaba (2006) revealed that the effective management of maintenance operations is highly important to decision-makers in the industry as cost could be conserved in the deployment of labour, strategies for development and actualization of techniques modelling for efficient maintenance implementation and scheduling.

Figure 1 shows the configuration concepts of machines monitoring and the need for decision-support tools as this reflects the tasks that require decision-taking on such as what to produce, how to produce, when to produce and which maintenance strategy to use in keeping the manufacturing enterprise alive from being moribund and to stand competitively.

A comprehensive predictive maintenance management program utilizes a combination of the most cost-effective tools, i.e. thermal imaging, vibration monitoring, tribology, and other nondestructive testing methods, to obtain the actual operating condition of critical plant systems, and based on these factual data, maintenance activities on an as-required basis are scheduled. Condition-based maintenance or predictive maintenance in a comprehensive maintenance management program will provide the ability to optimize the availability of process machinery and greatly reduce the cost of maintenance.

Condition-based maintenance strategy has recorded progressive report in recent times characterised by models and simulation addressing failure prediction problems; however, germane issues are still not fully integrated to make this technology result-oriented. Jardine et al. (2006), Lee et al. (2004) pointed out that enhanced technologies such as indicators for enhanced monitoring; fast signal processing algorithms, fast and precise prognostic approach, new alarm setting, tools for system performance assessment and degradation have not been developed.

$\mathrm{Ni}$ and Yang (2010) proposed a novel mechanism of intelligent condition monitoring and prognostic system based on data fusion strategy which is constructed under the architecture of open system, condition-based monitoring and prognostic modules. The mechanism utilizes fusion condition, automatic alarm setting, nonlinear prediction models and assessment. Chryssolouris et al. (2004) presented pilot implementation approach of human performance in virtual manufacturing environments by employing simulation principles of both virtual reality and digital mannequin technologies for the performance of industrial task.

The various maintenance models had been so helpful to the growth of industrial activities globally. There are still some limitations or extent to which these models and simulation techniques could be effectively utilized. Some of the previous works are considered and their limitations are spelt out in Table 1.

Despite all the enormous works covered in the aforementioned studies, there is still a missing gap, and the missing link is that there have not been concerted efforts to link maintenance decision policy with manufacturing policy. Also, most of the existing models which either deal with maintenance or production rarely considered the

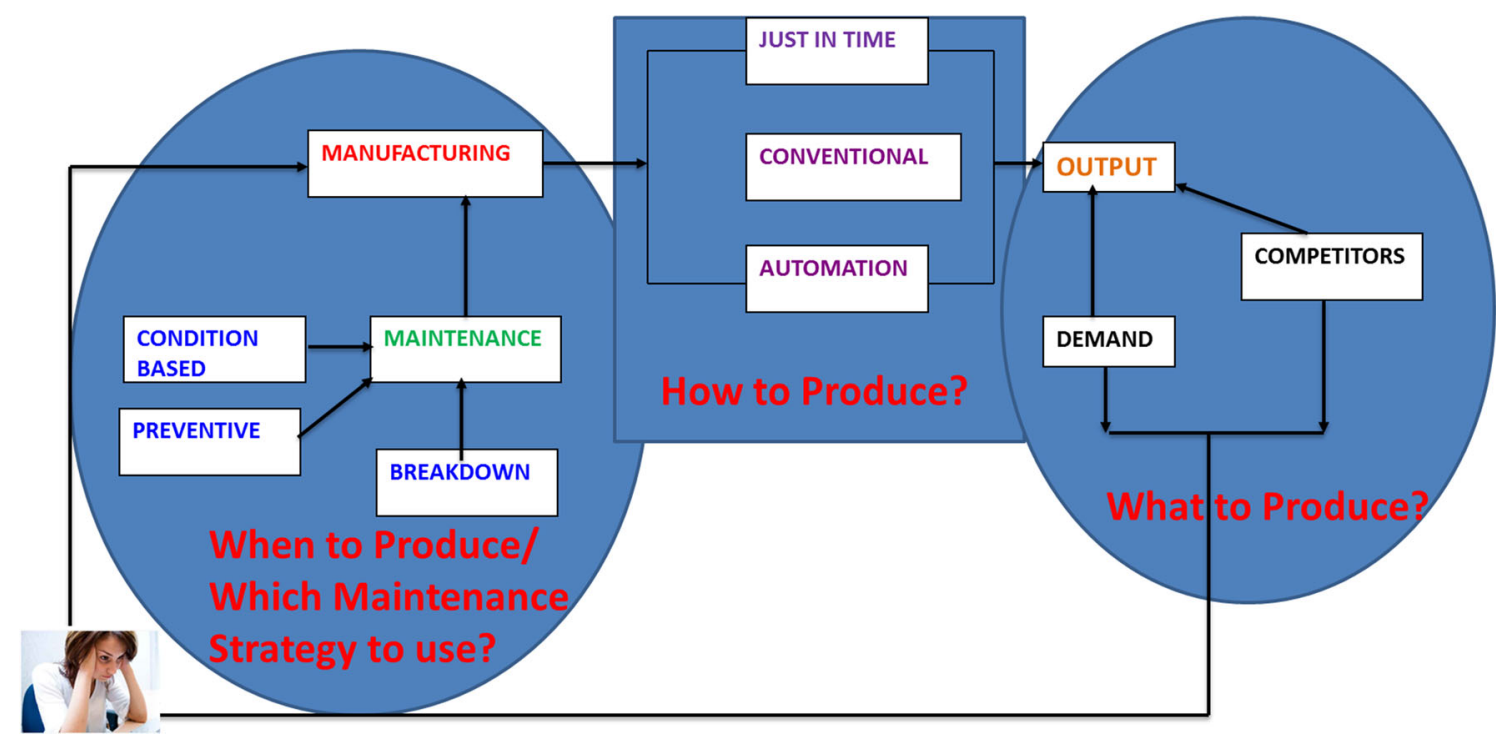

Fig. 1 Configuration concept of machines monitoring and the need for decision support tools 
Table 1 Comparison of past research models

\begin{tabular}{|c|c|c|c|}
\hline $\begin{array}{l}\mathrm{S} / \\
\mathrm{n}\end{array}$ & Authors & Contributions/summary of previous work done & Features of present work over the past researches \\
\hline 1 & $\begin{array}{l}\text { Lee and } \\
\text { Rosenblatt } \\
(1987)\end{array}$ & $\begin{array}{l}\text { Presented an optimization model for the case of simultaneous } \\
\text { production cycle and inspection schedule determination }\end{array}$ & $\begin{array}{l}\text { Maintenance and inventory are left on discussed } \\
\text { which is being taken into consideration }\end{array}$ \\
\hline 2 & $\begin{array}{l}\text { Albino et al. } \\
\text { (1992) }\end{array}$ & $\begin{array}{l}\text { Study of the effect of maintenance policies on just-in-time } \\
\text { manufacturing }\end{array}$ & $\begin{array}{l}\text { Covers more than JIT, it extends to other } \\
\text { manufacturing strategies }\end{array}$ \\
\hline 3 & $\begin{array}{l}\text { Ben-Daya } \\
\text { (1999) }\end{array}$ & $\begin{array}{l}\text { Presented a model for integrated production maintenance and } \\
\text { quality for an imperfect process }\end{array}$ & $\begin{array}{l}\text { Production maintenance and quality for an imperfect } \\
\text { process with epileptic power supply is just a part in } \\
\text { the work }\end{array}$ \\
\hline 4 & $\begin{array}{l}\text { Jardine et al. } \\
\text { (1999) }\end{array}$ & $\begin{array}{l}\text { Developed an optimal maintenance program based on vibration } \\
\text { monitoring of critical bearings on machinery }\end{array}$ & $\begin{array}{l}\text { This handles more than bearings, it covers electric } \\
\text { motors as well }\end{array}$ \\
\hline 5 & $\begin{array}{l}\text { Yuan and } \\
\text { Chaing } \\
\text { (2000) }\end{array}$ & $\begin{array}{l}\text { Formulated an optimal maintenance policy for a production } \\
\text { system subject to aging and shocks }\end{array}$ & $\begin{array}{l}\text { This is a part in the whole proposed model and purely } \\
\text { dynamic }\end{array}$ \\
\hline 6 & Sterman (2000) & $\begin{array}{l}\text { Maintenance model covers the aspects affecting the overall } \\
\text { maintenance process and cost, such as worker training, reactive } \\
\text { versus proactive culture }\end{array}$ & $\begin{array}{l}\text { The model did not take care of dynamic strategies in } \\
\text { manufacturing which is a major work in this } \\
\text { research }\end{array}$ \\
\hline 7 & $\begin{array}{l}\text { Duffuaa et al. } \\
\text { (2001) }\end{array}$ & $\begin{array}{l}\text { Provided a conceptual model that can be used to develop a } \\
\text { realistic simulation }\end{array}$ & Dynamic maintenance model forms bulk of the work \\
\hline 8 & $\begin{array}{l}\text { Zineb and } \\
\text { Chadi (2001) }\end{array}$ & $\begin{array}{l}\text { Establishment of an effective way of modeling complex } \\
\text { manufacturing systems through hierarchical and modular } \\
\text { analysis using stochastic Petri nets and Markov chains }\end{array}$ & $\begin{array}{l}\text { Model takes care of quality competitors with focus } \\
\text { on the up keeping of the production equipment in } \\
\text { order to deliver products with high and consistent } \\
\text { quality }\end{array}$ \\
\hline 9 & $\begin{array}{l}\text { Andijani and } \\
\text { Dufuaa } \\
\text { (2002) }\end{array}$ & $\begin{array}{l}\text { Review of various areas such as evaluation of maintenance } \\
\text { policies, organization, staffing, materials management and shut- } \\
\text { down policies }\end{array}$ & $\begin{array}{l}\text { It integrates the business model with both } \\
\text { maintenance and manufacturing model to become a } \\
\text { single model }\end{array}$ \\
\hline 10 & $\begin{array}{l}\text { Marquez et al. } \\
\text { (2003) }\end{array}$ & $\begin{array}{l}\text { Provided various maintenance optimization models for repairable } \\
\text { systems }\end{array}$ & It handles both repairable and non-repairable systems \\
\hline 11 & Greasly (2005) & $\begin{array}{l}\text { Showed that the discrete-event simulation study could be done } \\
\text { through system dynamics }\end{array}$ & $\begin{array}{l}\text { This is supporting the reality of the present approach } \\
\text { with quality competitors embedded }\end{array}$ \\
\hline 12 & $\begin{array}{l}\text { Mahantesh } \\
\text { et al. (2008) }\end{array}$ & $\begin{array}{l}\text { Integrated plant maintenance management application based on } \\
\text { artificial intelligence (AI) techniques, mainly knowledge-based } \\
\text { systems }\end{array}$ & $\begin{array}{l}\text { Competition is not part of the AI techniques, and this } \\
\text { is being handled in the present work }\end{array}$ \\
\hline 13 & $\begin{array}{l}\text { Papakostas } \\
\text { et al. } 2010\end{array}$ & $\begin{array}{l}\text { Discusses a maintenance decision support framework for } \\
\text { addressing short-term operational maintenance decisions at line } \\
\text { maintenance and for deferring maintenance actions that affect } \\
\text { the aircrafts' dispatching }\end{array}$ & $\begin{array}{l}\text { The decision support system did not consider market } \\
\text { competitiveness and it is solely for aircraft, while } \\
\text { the present paper addresses competitiveness and } \\
\text { centres on polyethelene bag production }\end{array}$ \\
\hline 14 & $\begin{array}{l}\text { Jasper et al. } \\
\text { (2011) }\end{array}$ & $\begin{array}{l}\text { Formulation of empirical postulates regarding the technical } \\
\text { system, managerial system and workforce knowledge }\end{array}$ & $\begin{array}{l}\text { Formulation of models with regards to machines } \\
\text { maintenance and products' quality }\end{array}$ \\
\hline 15 & $\begin{array}{l}\text { Golmakani and } \\
\text { Fattahipour } \\
\text { (2011) }\end{array}$ & $\begin{array}{l}\text { Proposed an approach in which preventive and failure } \\
\text { replacement costs as well as inspection cost are taken into } \\
\text { account to determine the optimal replacement policy and an } \\
\text { age-based inspection scheme }\end{array}$ & $\begin{array}{l}\text { The production and competition were not considered } \\
\text { and these form a part of the work under } \\
\text { consideration }\end{array}$ \\
\hline 15 & $\begin{array}{l}\text { Kareem and } \\
\text { Owolabi } \\
\text { (2012) }\end{array}$ & $\begin{array}{l}\text { Formulation of dynamic programming models for optimizing } \\
\text { maintenance planning using Markov chains, transition matrices }\end{array}$ & $\begin{array}{l}\text { This only addresses maintenance, but the present } \\
\text { model incorporates maintenance and production } \\
\text { under competitive environment }\end{array}$ \\
\hline
\end{tabular}

effect of competition which is addressed by this paper. The paper shall be considered under the following sections: "Model development" outlines the methods involved in developing the production of machines monitoring software; the validation and verification of the development system are enclosed in "Modelling concept for monitoring"; and finally, last section summarizes the conclusion of the work.

\section{Methodology}

The following steps are the approaches adopted in achieving the aim of the research:

1. Model development for manufacturing, maintenance activities and their linkages;

2. Modelling of monitoring concept;

3. Software development. 


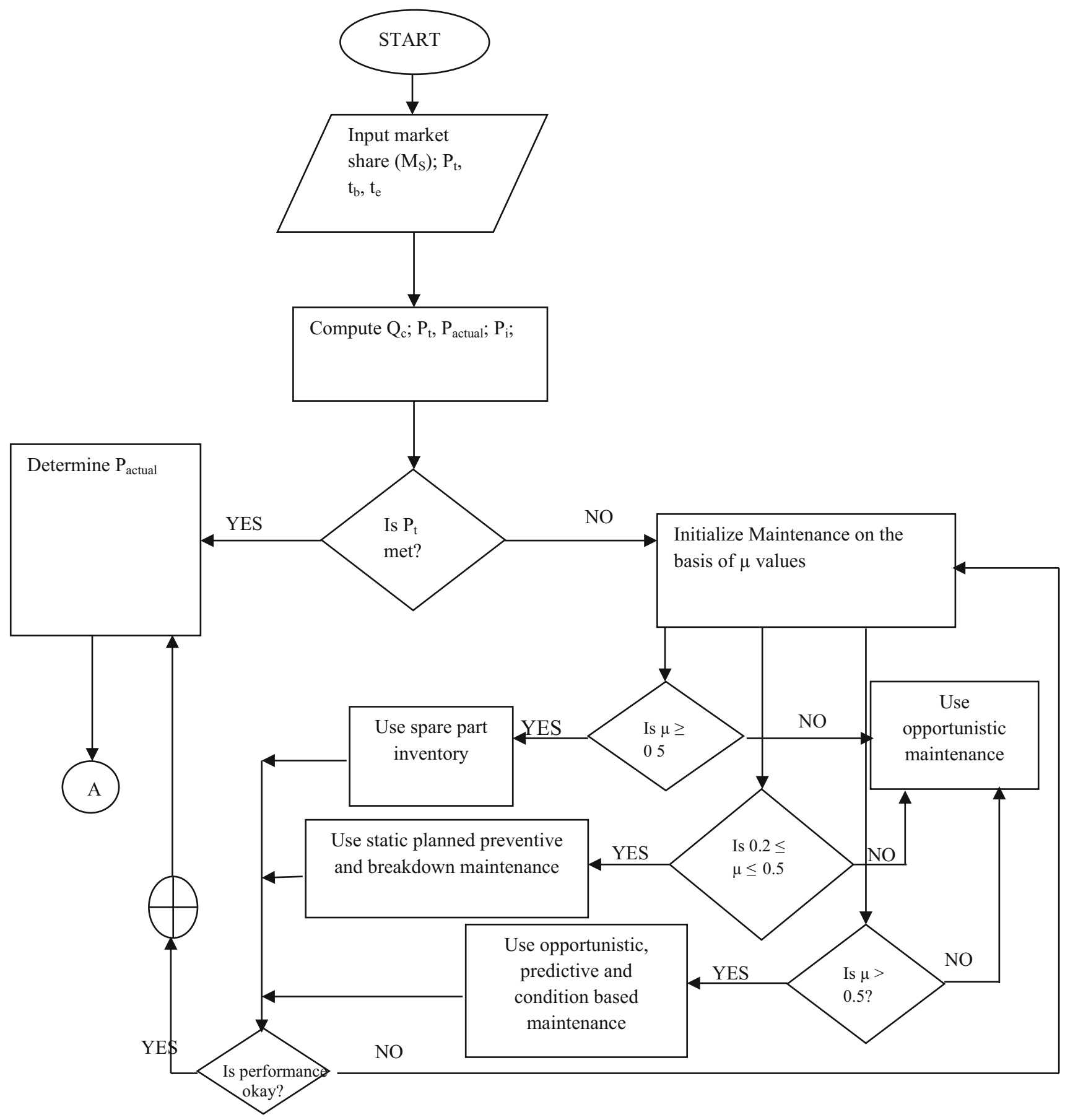

Fig. 2 Flowchart of dynamic model for strategies in maintenance prediction (Adeyeri et al. 2015)

\section{Model development}

The model development is based on the strategic decisions for both manufacturing and maintenance activities. Adeyeri and Kareem (2012) had once formulated models as assistance for carrying out comprehensive maintenance activities plan as at when due and at the point when machines are under stress to meeting up with customers' demand under competitive environment. The salient parameters needed for the achievement of the present work shall be discussed. Under the strategic decisions for manufacturing, the following parameters are considered: demand; market share; advertising; price changes; inventory; competition; and mode of operations/production methods, while types of maintenance, schedule of maintenance and its dynamics are covered under the strategic maintenance decision. 


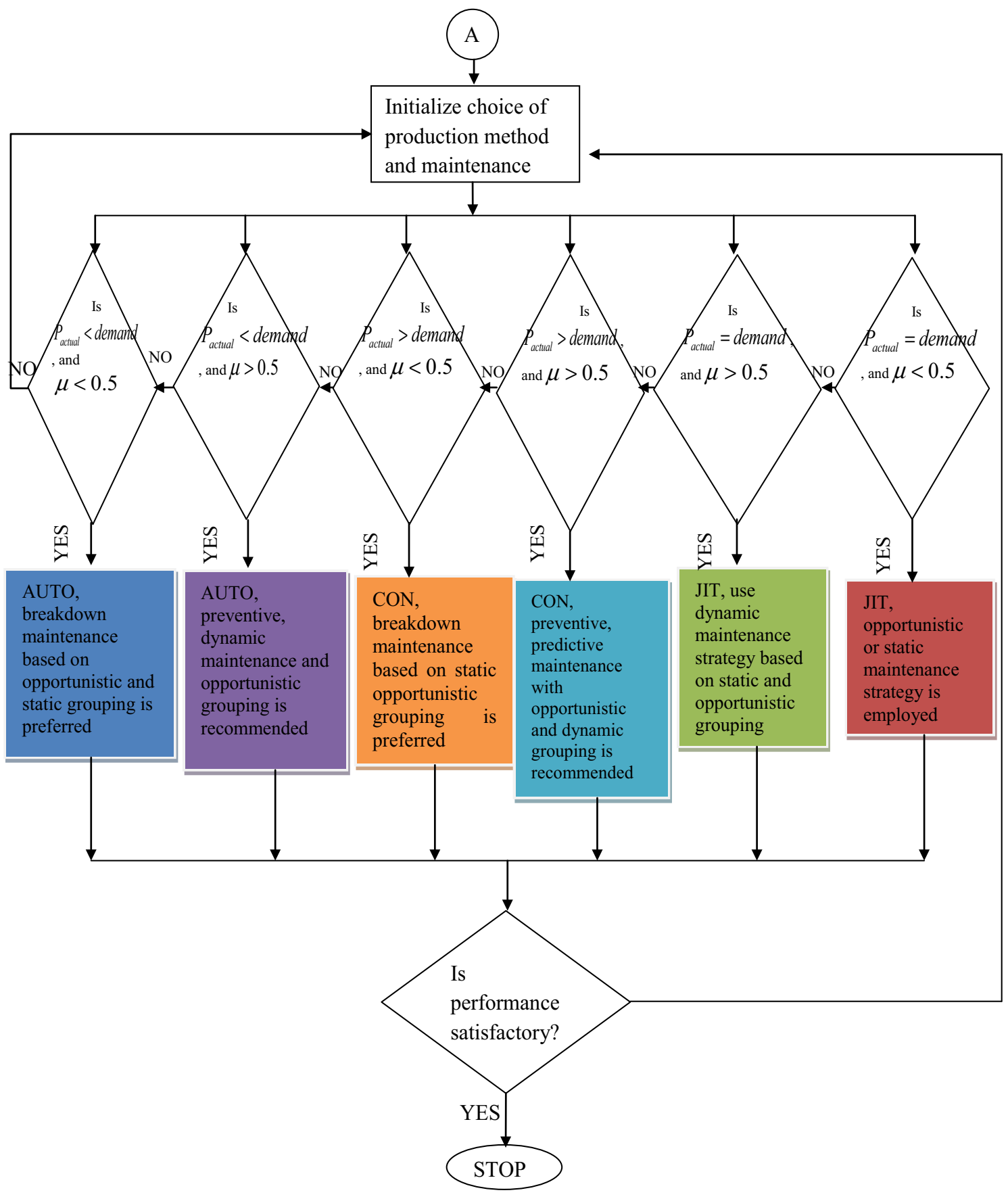

Fig. 2 continued

The flowchart used in the model formulation and modelling linkage of production and maintenance activities is as expressed in Fig. 2, while the mathematical formulation of the model can be found in the publication of Adeyeri and Kareem (2012) and Adeyeri et al. (2015). For clarity and brevity, the terms expressed in the flowchart are defined as $: M_{\mathrm{S}}$ (market share); $P_{\mathrm{t}}$ (total output); $t_{\mathrm{b}}$ (mean time to maintain machines i); $t_{\mathrm{e}}$ (expected running time of machine (1); $Q_{\mathrm{c}}$ (capacity of plant); $P_{\text {actual }}$ (actual production); $P_{\mathrm{i}}$ (total loss due to maintenance activity); and $\mu_{i}$ (range of severity).

\section{Modelling concept for monitoring}

The monitoring concept is mainly on hardware which comprises temperature and vibration sensors, AVR microcontroller (Atmega16; Atmega32); real time clock 


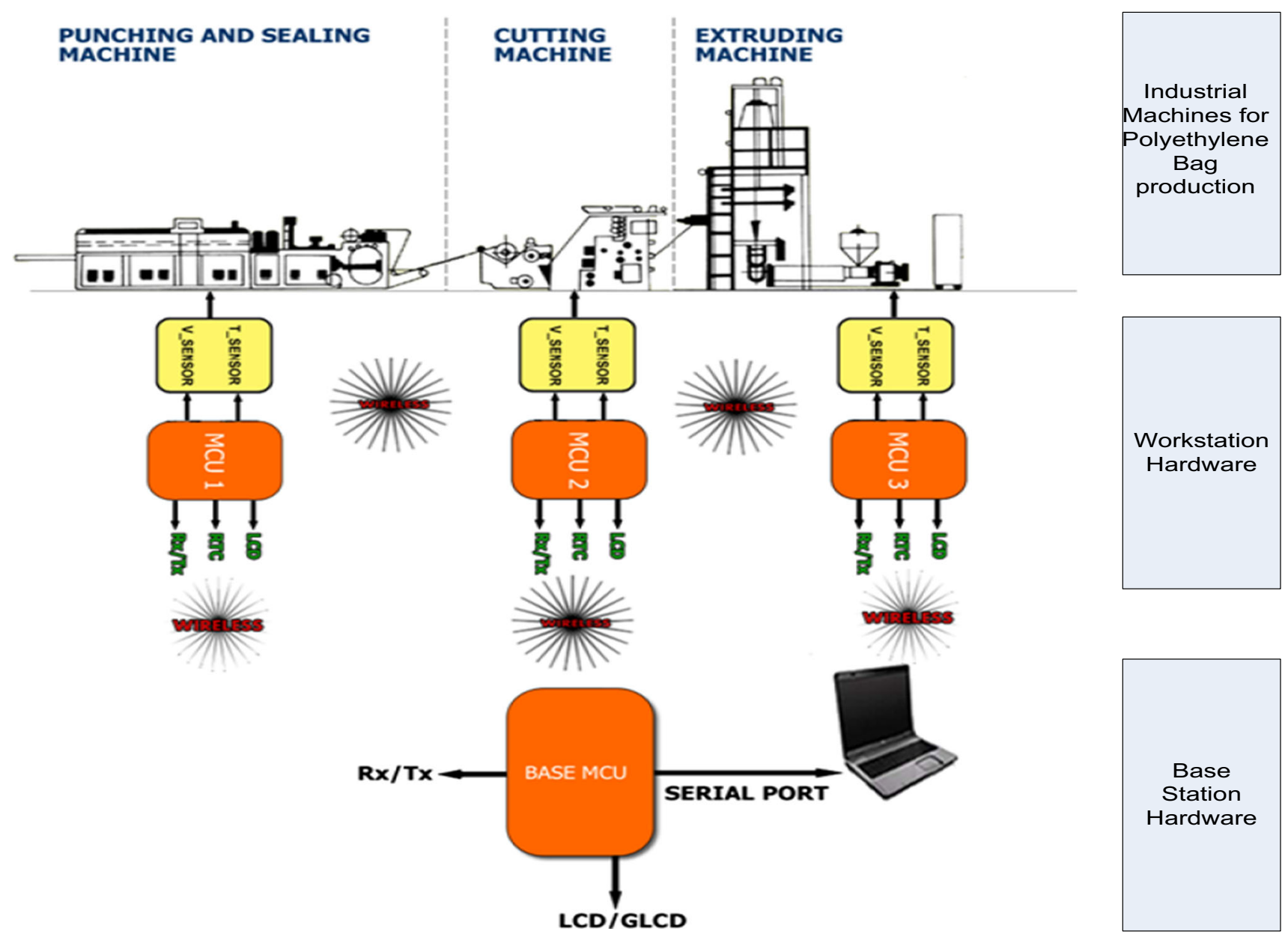

Fig. 3 Hardware architecture of the designed concept (Adeyeri et al. 2016)

(RTC); liquid crystal display (LCD), MJ MRF24J40MA (2.4 GHz ZigBee) transceiver, transformer, capacitor, resistors, MiKroC board platform, Vero board and other electrical components. The science behind the concept has been explained by the authors in an article entitled "Development of Hardware System using Temperature and Vibration Maintenance Models Integration Concepts for Conventional Machines Monitoring" (Adeyeri et al. 2016).

The modelling concept is designed to make use of the design shown in Fig. 3. Hardware is attached to the functioning machines at the workstation and machines data are transmitted through wireless network arrangement to the base station for maintenance and production decisions.

The maintenance decision is aided through the model flowchart of Fig. 4 structured by the authors as found in (Adeyeri et al. 2016). The acronyms in the flowchart are as defined here:

$V_{i+1}$ (predicted value of the vibration level at next planned measuring time); $t_{i+1}$ (elapsed time since damage is initiated and its development is detected); $V_{i}$ (current vibration level value); $Z_{i}$ : (deterioration factor); $V_{\mathrm{c}}$ (critical vibration level which is to be supplied by the manufacturer); $V_{\mathrm{o}}$ (measured vibration before $V_{i+1}$ ); a (gradient by which the value of the vibration level varied since it started to deviate from its normal state $\left(V_{\mathrm{o}}\right)$ due to initiation of damage until detection); $b_{i}$ and $c_{i}$ (nonlinear model's constants); $K$ (function of loading, speed of machine, environmental condition); $E_{i}$ (model error, which is assumed to be identical, independent and normally distributed with zero mean and constant variance, $\mathrm{N}(0, \sigma)$.

The decision to be made is strongly based on this arrangement coupled with the software provision which is to be explained in the subsequent section.

\section{Software development}

The software model developed was based on the integration of all the aforementioned methods described above. A section of the software is designed to monitor machines 


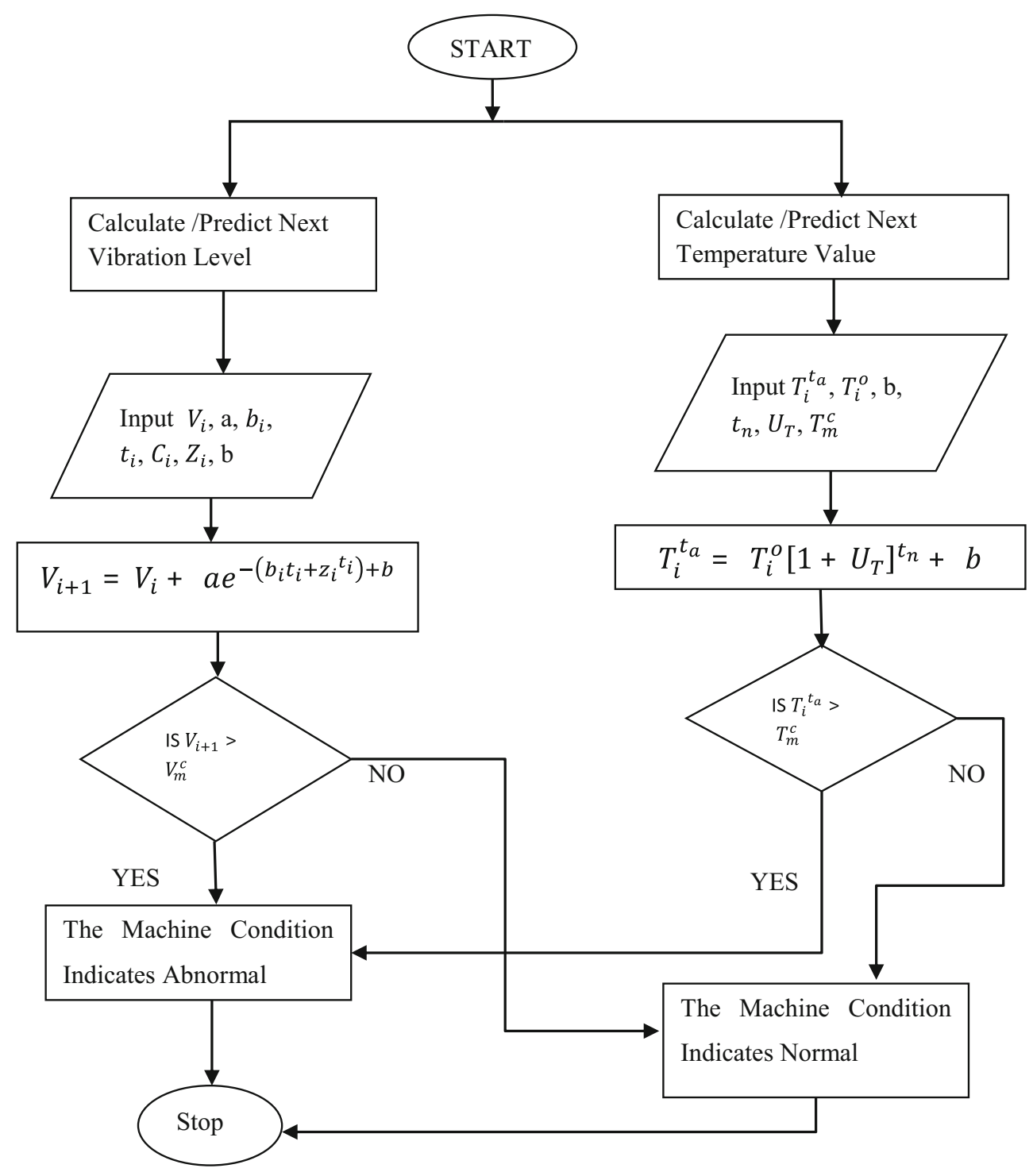

Fig. 4 Flowchart of condition-based maintenance monitoring (Adeyeri et al. 2016)

Fig. 5 Opening interface form of the PMCMS

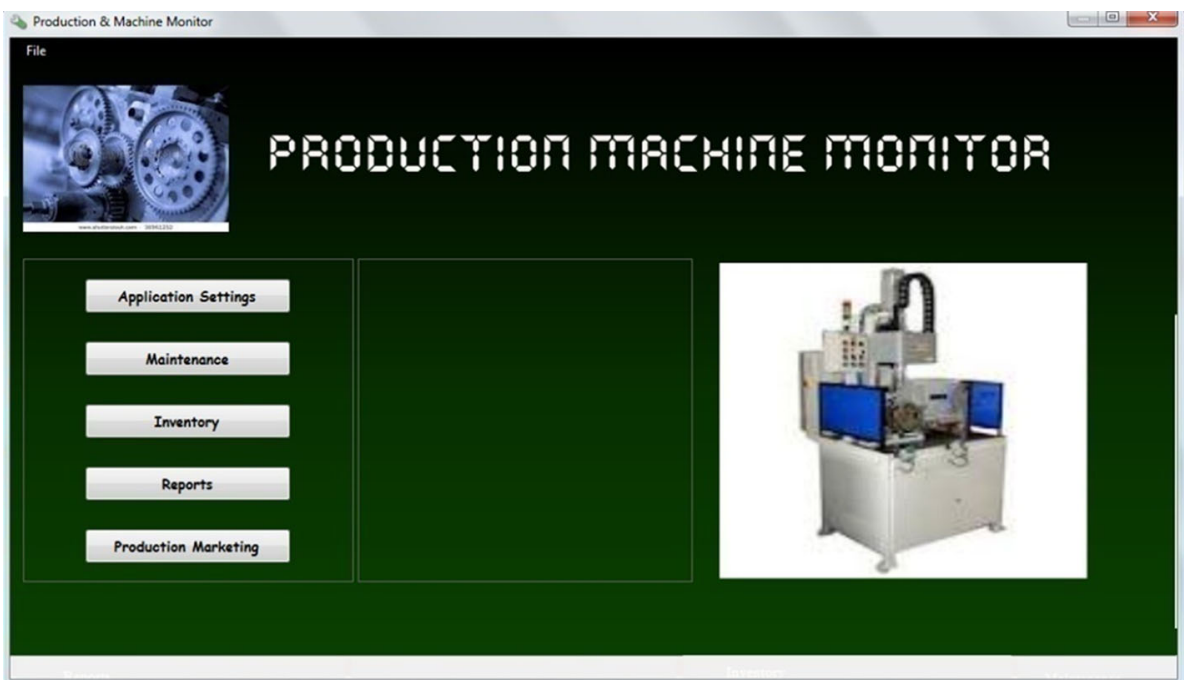




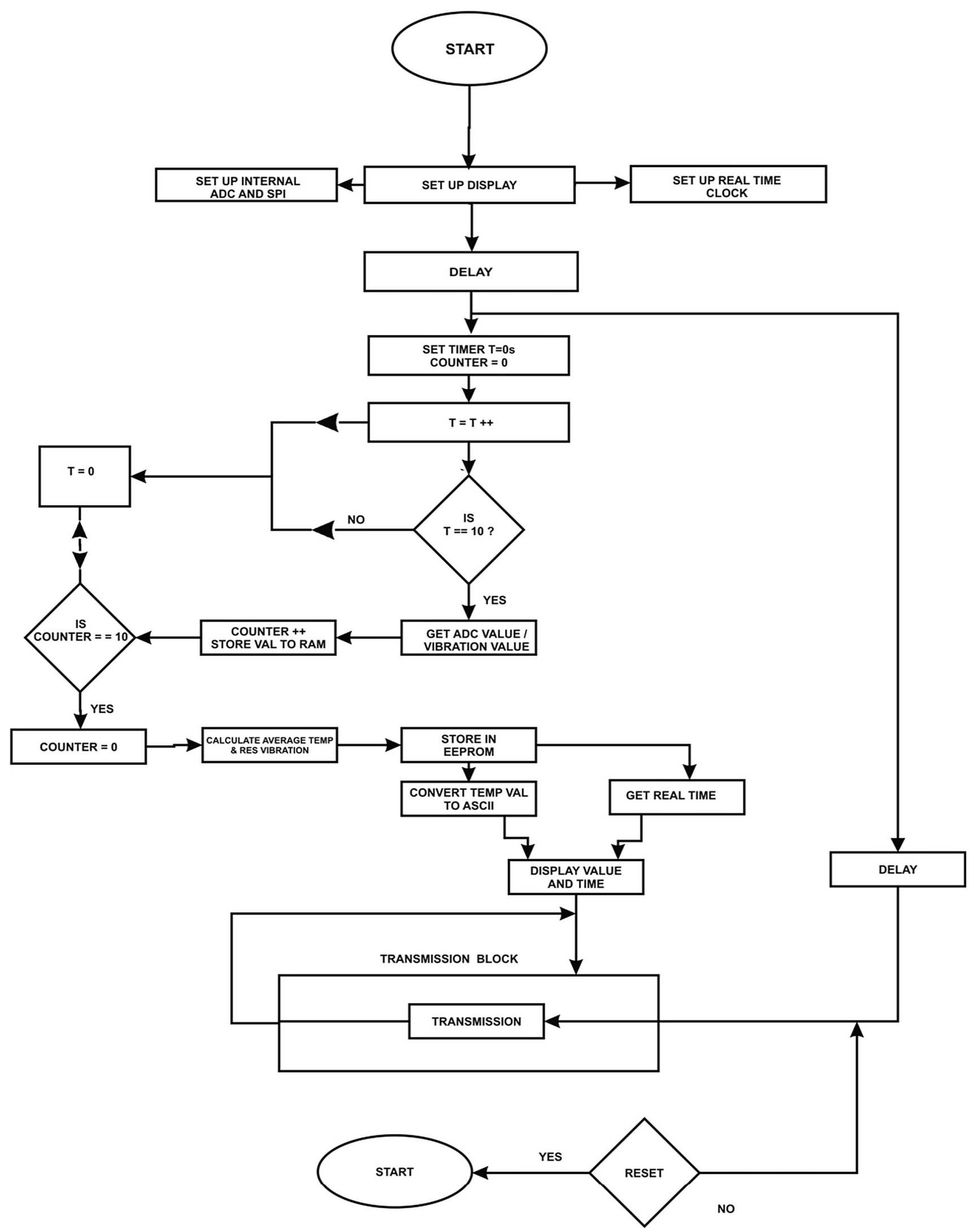

Fig. 6 Flowchart for sub-station module 
behavior under various conditions using vibration and temperature as key factors. The programming was done using Microsoft Studio Visual C\# because of its extensibility. The modules of the software are as discussed below.

\section{Scope of the production and machine condition monitoring software (PMCMS)}

The production and machine condition monitoring software (PMCMS) was developed to aid in monitoring the condition of production machines, suggesting production strategies to adopt, computing market share values, cost of production after certain parameters have been specified, and displaying the status of the machines' health behavior over a specified period of time.

PMCMS was designed such that it works with an embedded device which feeds it with data from the various machines being monitored. The data are read and stored in a database. An algorithm is used to process the data and the results are displayed as reports which can be exported to PDF, EXCEL, or WORD formats. The relationships between the various data accumulated are plotted as graphs. By containing all these features, the PMCMS aims to reduce the cost incurred from consulting external firms for services such as the business strategy to adopt, determining the cost of production, computing the plant's market share, determining the working state of individual machines and prediction of the states of the machines over a given period of time.

\section{Description of PMCMS}

The followings are the list of functionalities of the various windows available on the PMCMS software.

\section{Select port page}

At the launch of the application, a port selection page is met. This allows the user to determine the port to which the hardware is connected. The dropdown menu displays a list of available ports currently on the system.

\section{Home screen}

The home screen is the main page of the application. All other windows are designed as child forms of it. Please note that if this window is closed, the application exits completely. The home screen consists of a sub-window that displays the current reading from the hardware concerning the status of the machines being monitored. At the top of the home screen is a menu bar. The menu bar contains access to a list of other functional pages available for the application.
The opening interface of the developed software named production and machine condition monitoring software (PMCMS) is shown in Fig. 5.

\section{Software development for sub-station and base station hardware}

The embedded code development for the hardware development and utilization as embedded system was achieved through the use of $\mathrm{C}$ language on MiKroC platform.

\section{Sub-station and base station flowchart}

The flowchart used in coding the temperature sensor and the vibration sensor to give room for the computer machine interface under the $\mathrm{C}$ language is as shown in Fig. 6. The base station flowchart for the programming of the hardware used is as shown in Fig. 7.

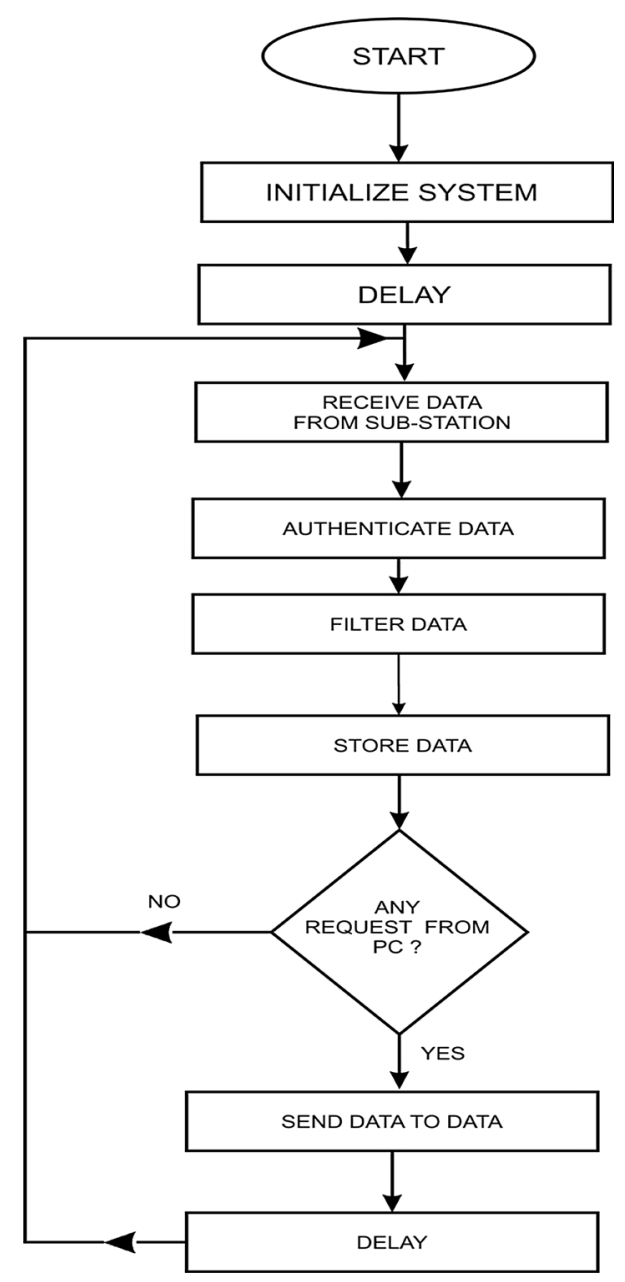

Fig. 7 Flowchart for hardware development 


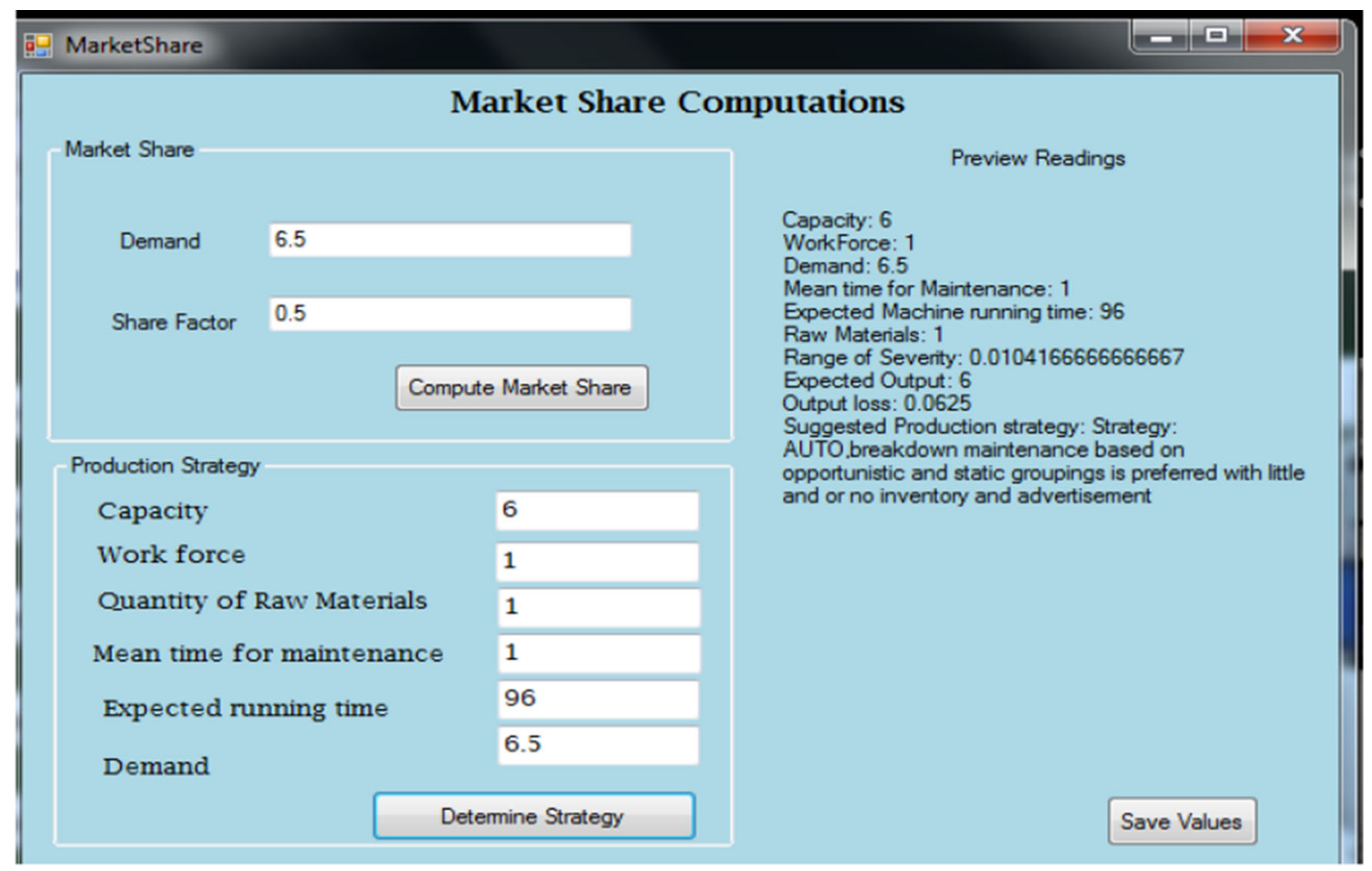

Fig. 8 Form for a typical output of PMCMS market share interface for first period

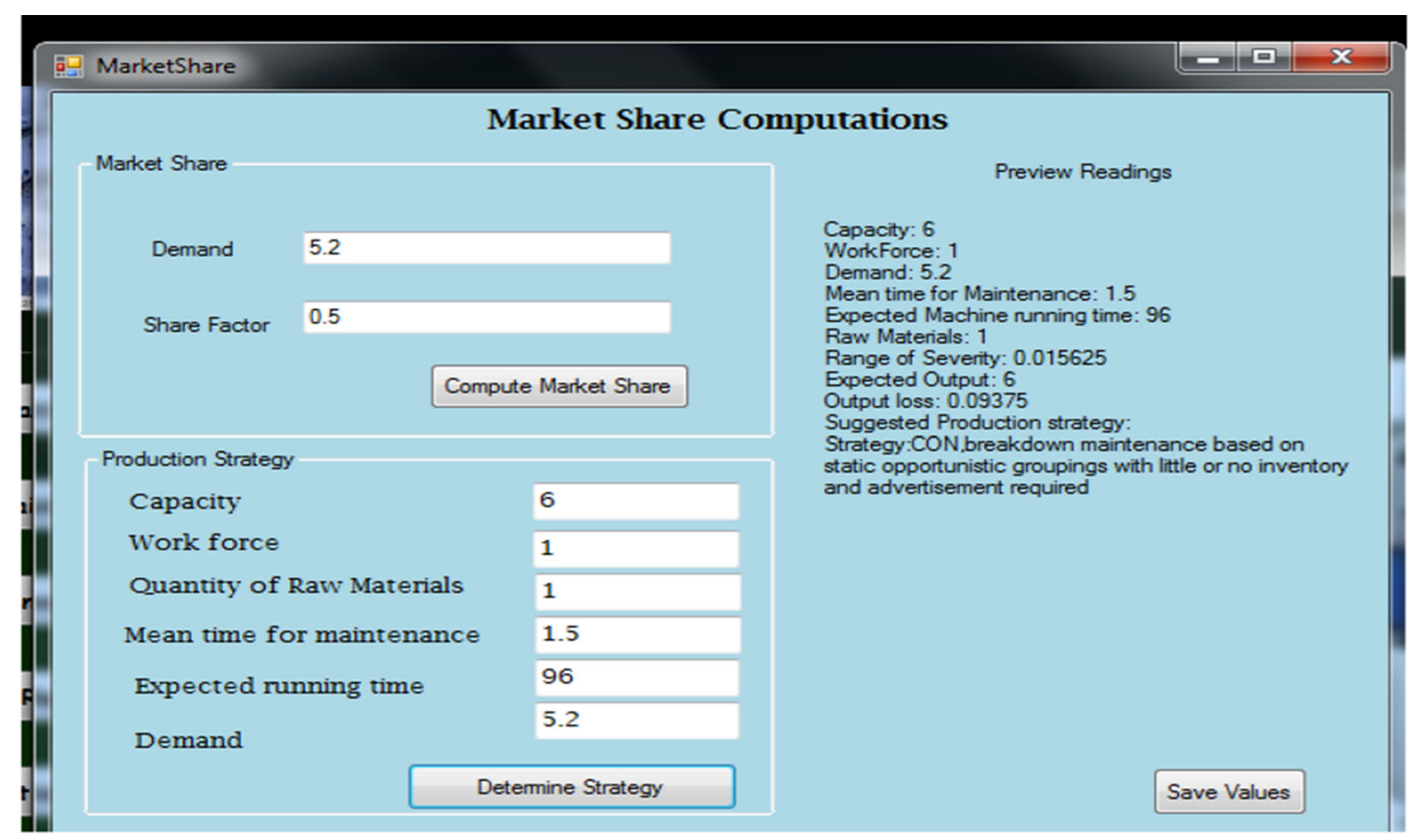

Fig. 9 Form for a typical output of PMCMS market share interface for second period

\section{Results and discussion}

The implementation of the PMCMS is considered in respect of machines' production activities and their maintenance modules. The PMCMS was used on machines involved in the production of a polyethylene bag so as to verify and test the validity of the developed software. This section shall be considered looking at model implementation of machines' production activities and maintenance of machines based on machine condition monitoring. 


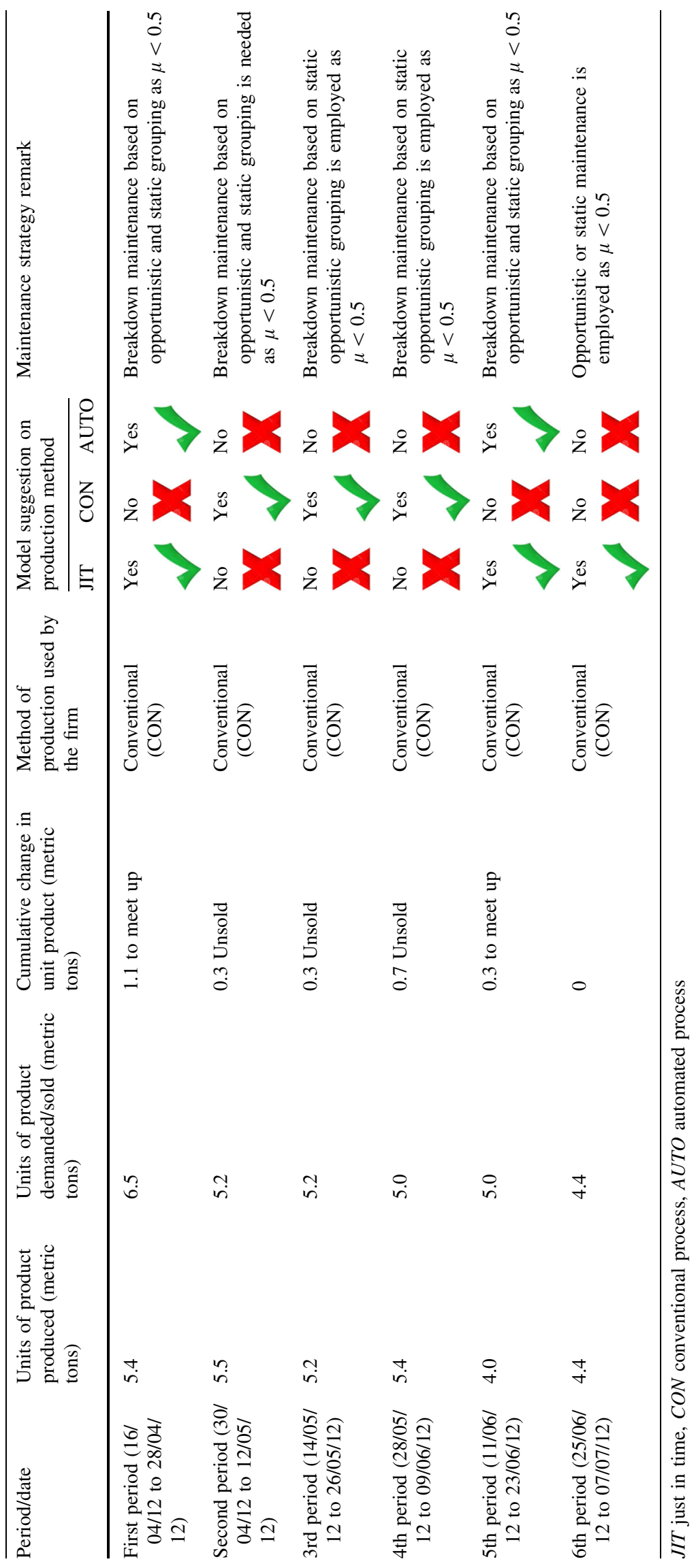




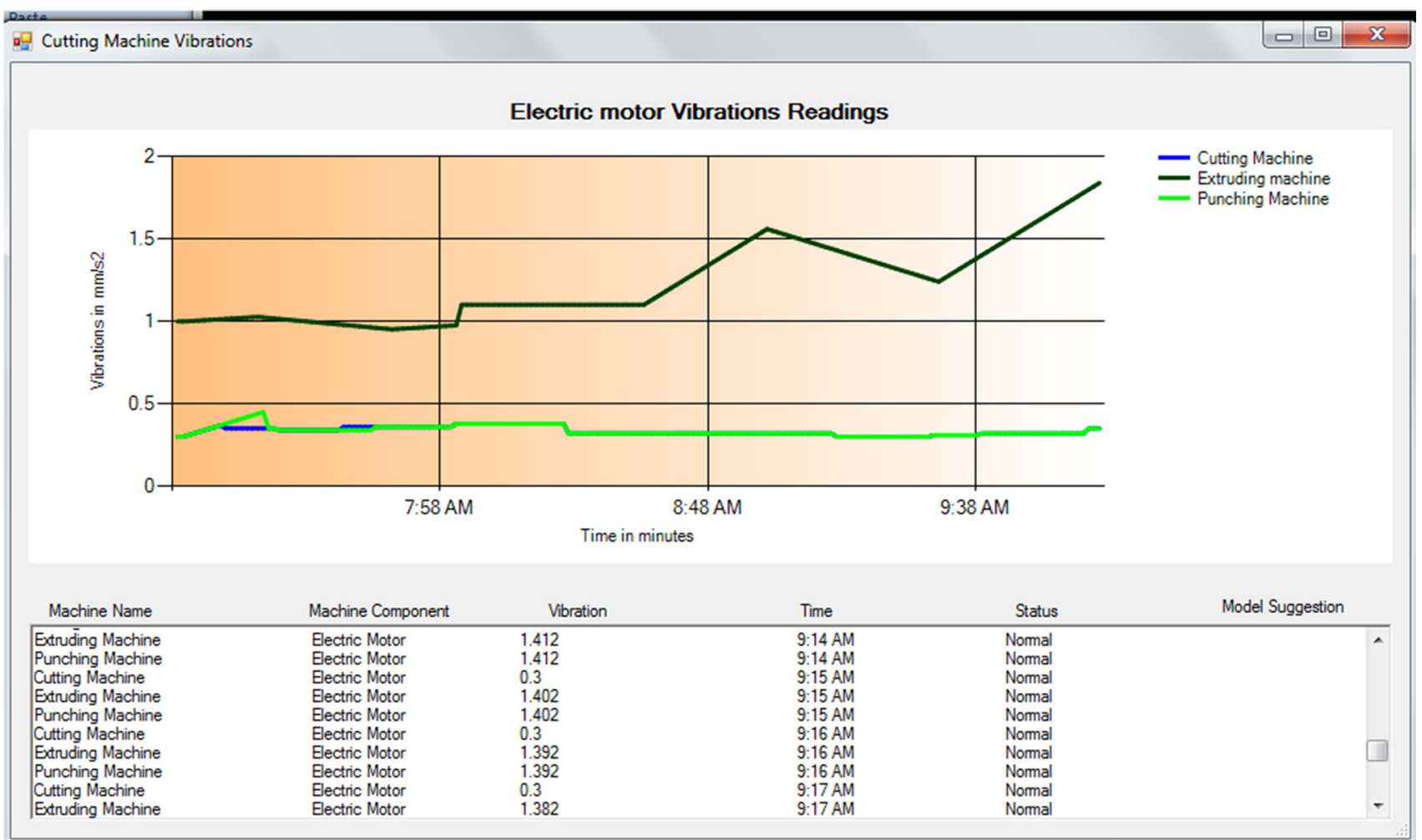

Fig. 10 Form for a typical output of vibration data from electric motors

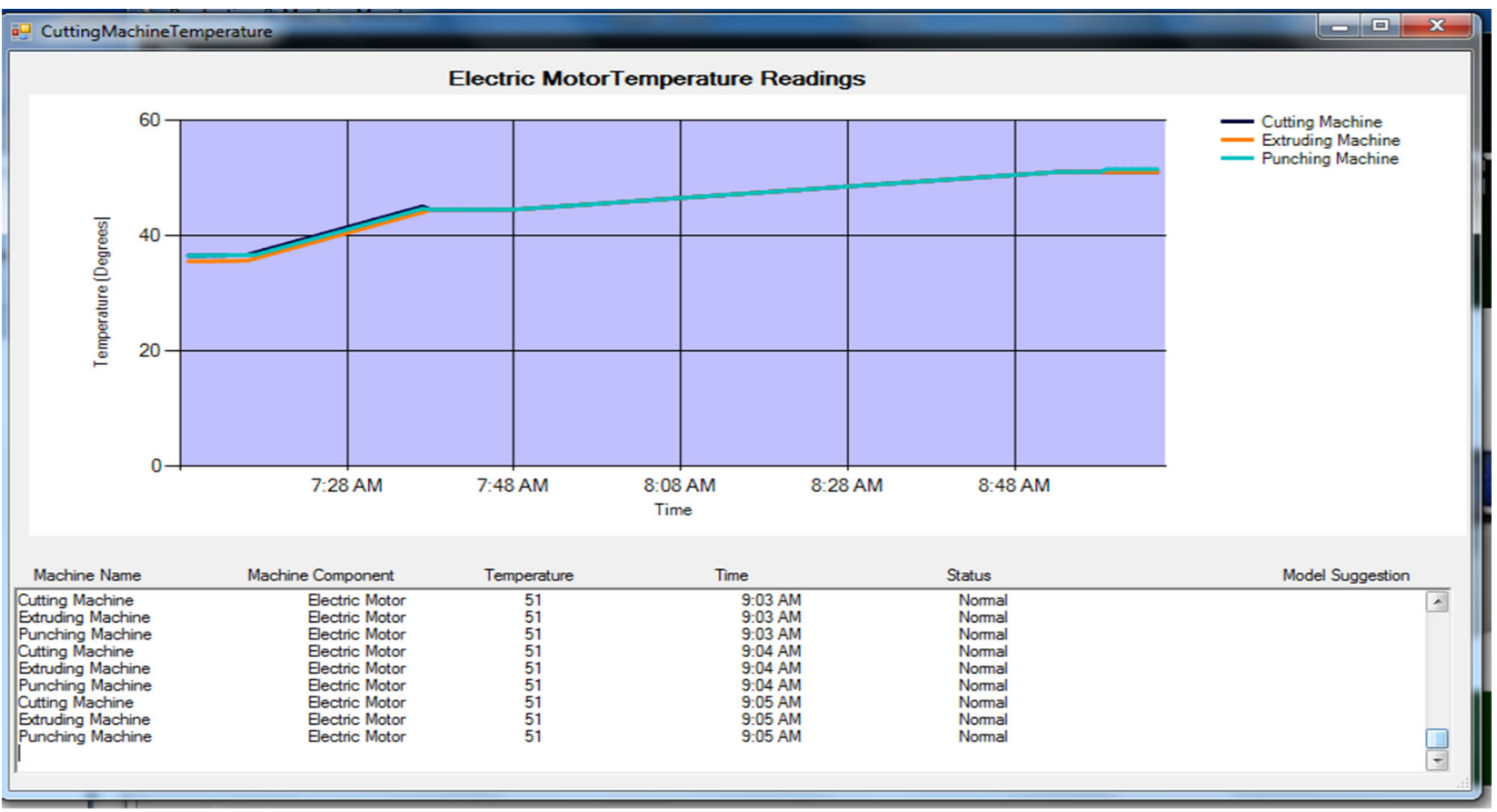

Fig. 11 Form for a typical output of temperature data from electric motors 


\section{Model implementation of machines' production}

The production data (production capacity, the workforce required, quantity of raw materials needed), production hours, amount of product sold and other parameters which had been defined are supplied to the developed software. Some snapshots of samples displaying the software suitability are displayed in Fig. 8, and Figure 9 shows the summary of the results, the various outcomes and possible maintenance suggestions; while Table 2 gives the detailed summary of transactions and the model suggestions on production processes and the maintenance strategies that need to be adopted as the demand for the polyethylene bag changes due to its competitiveness under the period of review.

From Table 2 and Fig. 8, in the first period (16/04/ $12-28 / 04 / 12$ ), the industry sold 5.4 tons of polyethylene bag produced, but could not meet the demand of 1.1 tons to the customer. In view of this, the PMCMS gave suggestion on decisions to take in meeting up for such shortfall by adopting just-in-time (JIT) or automatic production approach with the best maintenance decision of "breakdown maintenance based on opportunistic and static grouping as $\mu<0.5$ ". In the second period, with a clue from Fig. 9, 5.2 tons were demanded for, but the industry's production target was 5.5 tons, which implies that 0.3 tons were left unsold which forms part of the provision for inventory upkeep in the developed system. Thus, the PMCMS system gave decision suggestion in support of the conventional approach of production.

In the sixth period (25/06/12-07/07/12), market demand was in favour of the industry as total quantities produced were sold or demanded for. This was corroborated by the decision given by the PMCMS that JIT approach would be better for such trend of production.
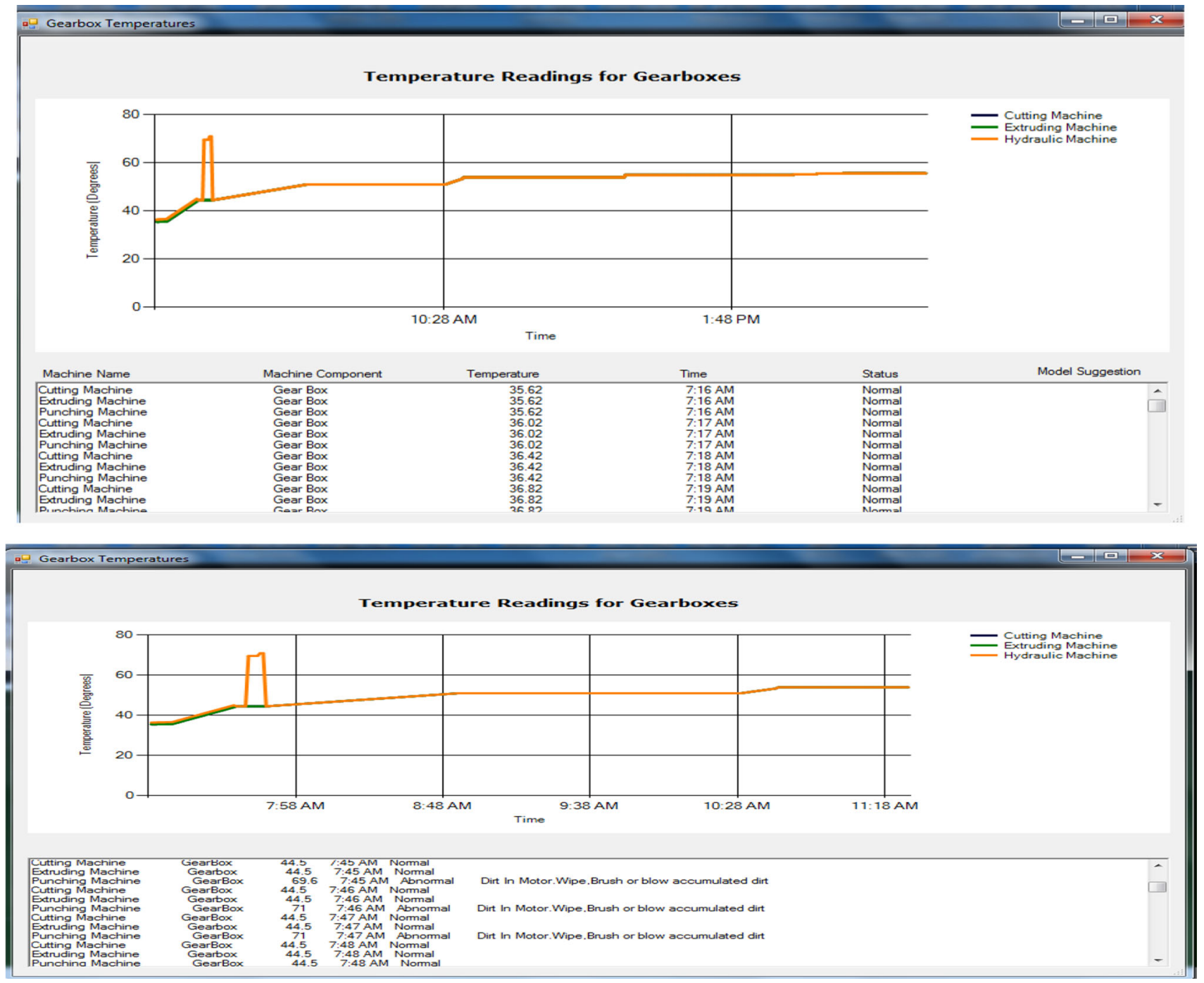

Fig. 12 Form for a typical output of temperature data from gearbox 


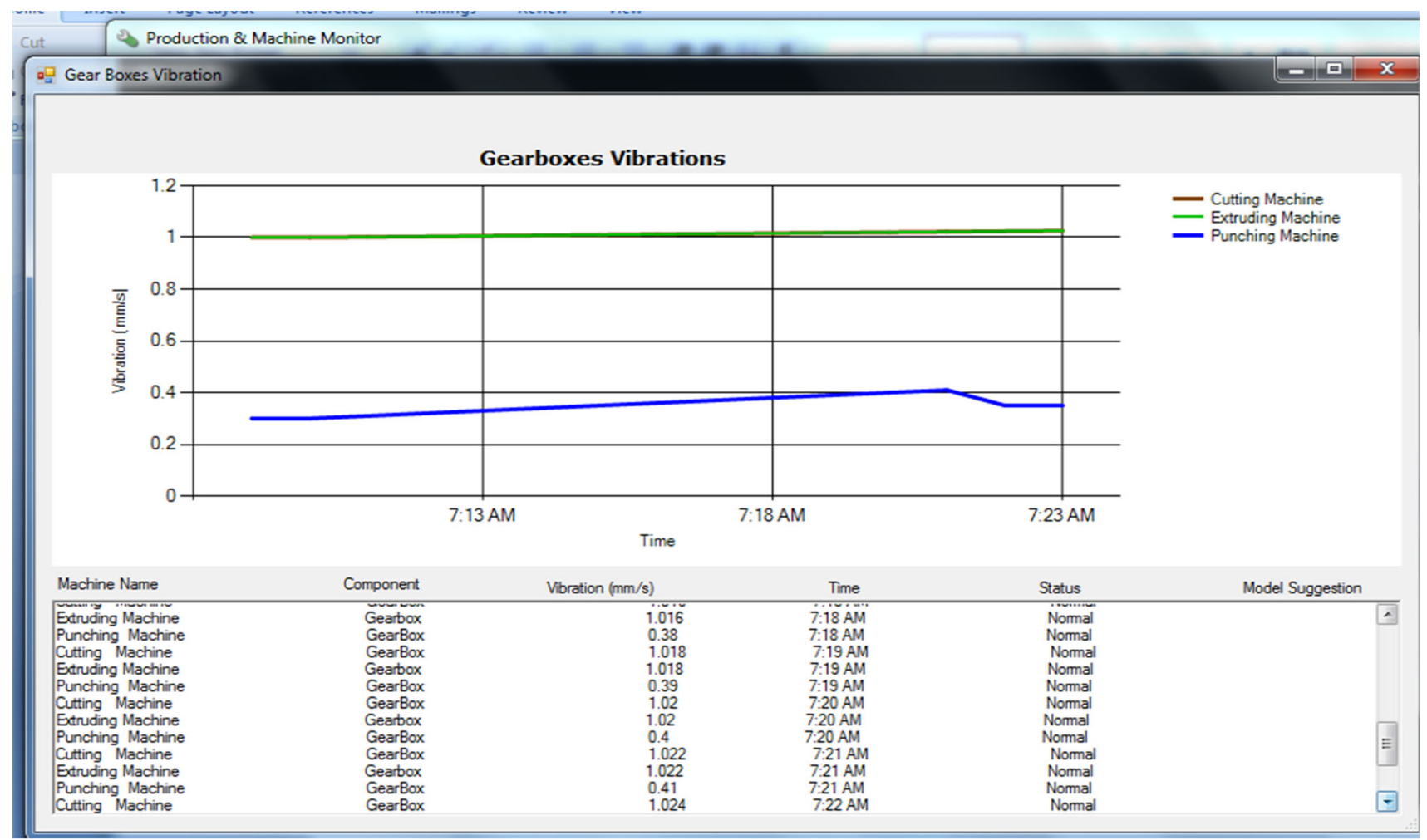

Fig. 13 Form for a typical output of vibration data from gearbox

The model was able to actualize the set purpose. It established the appropriate production and maintenance strategies that could survive the manufacturing industry under high competition and controllable demands.

\section{PMCMS machines condition monitoring implementation}

As discussed earlier, the modelling concept implementation is shown in this section. The built hardware as made known by the authors, Adeyeri et al. (2015), was part of the system put in place to perfect the PMCMS functionalities. The hardware when embedded into the machines with the support platform plugin in the PMCMS, monitoring of the behavior of the machines, as they are being run, is made possible. The various vibration and temperature trends monitored for the gearbox and electric motor of the machines/plant using the hardware are as shown in Figs. 10, 11, 12 and 13.

The summary of the vibration data trends read by the systems developed with the various prognostic measures and machine conditions is as displayed in Table 3.

As shown in Table 3, on April 16, 2012, the vibration readings sampled from the production process revealed that the vibration values of the extruder gearbox, cutting machine gearbox and punching machine gearbox read $0.970,0.980$ and $0.360 \mathrm{~mm} / \mathrm{s}$, respectively. And the corresponding condition status of these machines indicated that they are normal $(\mathrm{N})$. On May 14, 2012, 7.5, 1.28 and $1.20 \mathrm{~mm} / \mathrm{s}$ were recorded for the extruder, cutting machine and punching machine, respectively. On this note, the model gave a maintenance suggestion clue that the vibration abnormality of extruder gearbox is a result of misalignment and coupling wear. Looking through the entire Table 3, it has been shown that the model algorithm is correct as it could distinguish between when the machine conditions are normal, abnormal, and then display maintenance suggestion messages which are valid and resultoriented.

\section{Conclusion}

Conclusively, the right decision on choice of production, maintenance strategy, pricing and advertisement could be predicted using this PMCMS with a positive effect on profitability of the manufacturing system, and ability to meet customers' needs. The software was able to assist in taking appropriate maintenance decision on machinery, thereby reducing the failure rate and thus correcting products backlog and enhancing the equipment effectiveness, management of machinery and products flow.

The study has established that decision on the efficient and optimum performances of machines lies on the prompt 
Table 3 Gearbox vibration readings and maintenance model suggestion decision for extruder, cutting and punching machines

\begin{tabular}{|c|c|c|c|c|c|c|c|c|c|}
\hline \multirow[t]{2}{*}{$\begin{array}{l}\text { Sampling } \\
\text { dates }\end{array}$} & \multicolumn{3}{|c|}{$\begin{array}{l}\text { Extruder's gearbox vibration }(\mathrm{mm} / \mathrm{s}) \text {, } \\
\text { conditions and decision }\end{array}$} & \multicolumn{3}{|c|}{$\begin{array}{l}\text { Cutting machine gearbox vibration }(\mathrm{mm} / \\
\mathrm{s}) \text {, conditions and decision }\end{array}$} & \multicolumn{3}{|c|}{$\begin{array}{l}\text { Punching machine gearbox vibration } \\
(\mathrm{mm} / \mathrm{s}) \text {, conditions and decision }\end{array}$} \\
\hline & $\begin{array}{l}\text { Vibration } \\
(\mathrm{mm} / \mathrm{s})\end{array}$ & Conditions & $\begin{array}{l}\text { Model decision } \\
\text { suggestion on } \\
\text { maintenance } \\
\text { activities }\end{array}$ & $\begin{array}{l}\text { Vibration } \\
(\mathrm{mm} / \mathrm{s})\end{array}$ & Conditions & $\begin{array}{l}\text { Model } \\
\text { decision } \\
\text { suggestion on } \\
\text { maintenance } \\
\text { activities }\end{array}$ & $\begin{array}{l}\text { Vibration } \\
(\mathrm{mm} / \mathrm{s})\end{array}$ & Conditions & $\begin{array}{l}\text { Model } \\
\text { decision } \\
\text { suggestion on } \\
\text { maintenance } \\
\text { activities }\end{array}$ \\
\hline $16 / 4 / 2012$ & 0.970 & $\mathrm{~N}$ & & 0.980 & $\mathrm{~N}$ & & 0.360 & $\mathrm{~N}$ & \\
\hline $18 / 4 / 2012$ & 0.350 & $\mathrm{~N}$ & & 0.350 & $\mathrm{~N}$ & & 0.300 & $\mathrm{~N}$ & \\
\hline $28 / 4 / 2012$ & 1.380 & $\mathrm{~N}$ & & 1.300 & $\mathrm{~N}$ & & 1.280 & $\mathrm{~N}$ & \\
\hline $30 / 4 / 2012$ & 1.400 & $\mathrm{~N}$ & & 1.320 & $\mathrm{~N}$ & & 1.240 & $\mathrm{~N}$ & \\
\hline $10 / 5 / 2012$ & 1.340 & $\mathrm{~N}$ & & 1.240 & $\mathrm{~N}$ & & 1.180 & $\mathrm{~N}$ & \\
\hline $14 / 5 / 2012$ & 7.500 & A & $\begin{array}{l}\text { Misalignment } \\
\text { and coupling } \\
\text { wear. Stop } \\
\text { machine for } \\
\text { repairs }\end{array}$ & 1.280 & $\mathrm{~N}$ & & 1.200 & $\mathrm{~N}$ & \\
\hline $15 / 5 / 2012$ & 0.820 & $\mathrm{~N}$ & & 1.200 & $\mathrm{~N}$ & & 1.100 & $\mathrm{~N}$ & \\
\hline $18 / 5 / 2012$ & 1.100 & $\mathrm{~N}$ & & 1.250 & $\mathrm{~N}$ & & 0.880 & $\mathrm{~N}$ & \\
\hline $28 / 5 / 2012$ & 1.460 & $\mathrm{~N}$ & & 1.200 & $\mathrm{~N}$ & & 1.200 & $\mathrm{~N}$ & \\
\hline $09 / 6 / 2012$ & 2.000 & $\mathrm{~N}$ & & 1.240 & $\mathrm{~N}$ & & 2.200 & $\mathrm{~N}$ & \\
\hline $11 / 6 / 2012$ & 1.220 & $\mathrm{~N}$ & & 4.700 & A & $\begin{array}{l}\text { Mechanical } \\
\text { looseness, } \\
\text { stop machine }\end{array}$ & 1.800 & $\mathrm{~N}$ & \\
\hline $22 / 62012$ & 1.200 & $\mathrm{~N}$ & & 2.240 & $\mathrm{~N}$ & & 1.340 & $\mathrm{~N}$ & \\
\hline $25 / 6 / 2012$ & 1.800 & $\mathrm{~N}$ & & 1.880 & $\mathrm{~N}$ & & 0.960 & $\mathrm{~N}$ & \\
\hline $04 / 7 / 2012$ & 1.600 & $\mathrm{~N}$ & & 1.900 & $\mathrm{~N}$ & & 1.400 & $\mathrm{~N}$ & \\
\hline
\end{tabular}

$N$ normal machine status, $A$ abnormal machine status

and real-time monitoring of the machine components and behavior; production machines, products demand and manufacturing processes could be knitted and monitored under the same module to support maintenance planning; and functionality with availability of machines is improved through integrated production and dynamic maintenance strategies in competitive environment.

Authors' contributions The collation, documentation and drafting of the research work was done by Dr. MKA. While Prof KM provided motivation and editorial services on the article.

Open Access This article is distributed under the terms of the Creative Commons Attribution 4.0 International License (http://crea tivecommons.org/licenses/by/4.0/), which permits unrestricted use, distribution, and reproduction in any medium, provided you give appropriate credit to the original author(s) and the source, provide a link to the Creative Commons license, and indicate if changes were made.

\section{References}

Adeyeri MK, Kareem B (2012) Maintenance dynamics tools for machines functionality in a competitive environment. Ind Eng Lett 2(7):12-19
Adeyeri MK, Mpofu K, Kareem B (2015) Modelling of product demand as pointer tool for choice of maintenance strategy. Afr J Sci Technol Innov Dev 7(2):144-150

Adeyeri MK, Mpofu K, Kareem B (2016) Development of hardware system using temperature and vibration maintenance models integration concepts for conventional machines monitoring: a case study. J Ind Eng Int 12(1):93-109

Albino V, Carella G, Okogbaa O (1992) Maintenance polices in justin-time manufacturing lines. Int J Prod Res 30:369-382

Alhad A, Xiaohui C, Jay L, Jun N and Ziming Y (2008) Optimized maintenance design for manufacturing performance improvement using simulation. In: Proceedings of the 40th Conference on Winter Simulation Conference, IEEE, pp 1811-1819

Andijani A, Duffuaa S (2002) Critical evaluation of simulation studies in maintenance systems. Prod Plan Control 13(4):336-341

Ben-Daya M (1999) Integrated production maintenance and quality model for imperfect processes. IIE Trans 31(6):491-501

Chryssolouris G, Mavrikios D, Fragos D, Karabatsou V, Alexopoulos K (2004) Analysis of assembly and maintenance processes using virtual reality and digital mannequin technologies. Virtual Augment Real Appl Manuf. doi:10.1007/978-1-4471-3873-0_6

Duffuaa SO, Ben-Daya M, Al-Sultan KS, Andijani AA (2001) A generic conceptual simulation model for maintenance systems. J Qual Maint Eng 7(3):34-40

Golmakani HR, Fattahipour F (2011) Age-based inspection scheme for condition-based maintenance. J Qual Maint Eng 17(1):93-110 (Emerald Group Publishing Ltd.) 
Greasly A (2005) Using system dynamics in a discrete-event simulation study of a manufacturing plant. Int $\mathrm{J}$ Oper Prod Manag 25(6):534-548

Jardine AKS, Joseph T, Benjevic D (1999) Optimising conditionbased maintenance decisions for equipment subject to vibration monitoring. J Qual Maint Eng 5(3):192-202. (http://www. emerald-library.com). Accessed June 2012

Jardine AKS, Lin D, Banjevic D (2006) A review on machinery diagnostics and prognostics implementing condition-based maintenance. Mech Syst Signal Process 20(7):1483-1510

Jasper V, Warse K, Hans W (2011) Managing condition-based maintenance technology, a multiple case study in the process industry. J Qual Maint Eng 17(1):40-62 [http://www.emeraldlibrary.com]. Accessed 13 June 2012

Kareem B, Owolabi HA (2012) Optimizing maintenance planning in the production industry using the markovian approach. Technol $\mathrm{J}$ Eng Res 9(2):46-63

Lee HL, Rosenblatt MJ (1987) Simultaneous determination of production cycle and inspection schedule in a production system. Manag Sci 33(9):1125-1136

Lee J, Qiu H, Ni J, Djurdjanovi D (2004) Infortronics technologies and predictive tools for next-generation maintenance systems. IN: 11th IFAC Symposium on information control Problems in Manufacturing

Liliane P, Srinivas KP, Ann V (2006) Evaluating the effectiveness of maintenance strategies. J Qual Maint Eng 12(12):7-20 (Emerald Group Publishing Ltd.)
Mahantesh N, Ramachandra A, Satosh Kumar AN (2008) Artificial intelligence-based condition monitoring for plant maintenance. Assem Autom 28(2):143-150

Marquez CA, Gupta JND, Herguedas SA (2003) Maintenance policies for a production system with constrained production rate and buffer capacity. Int J Prod Res 41(9):1909-1926

Ni G, Yang B-S (2010) Intelligent condition monitoring and prognostics system based on data-fusion strategy. Expert Syst Appl 37:8831-8840

Oke SA, Charles-Owaba OE (2006) An approach for evaluating preventive maintenance scheduling cost. Int J Qual Reliab Manag 23(7):847-879

Ólafsson S, Kim J (2002) Simulation Optimization. In: Yücesan E, Chen CH, Snowdon JL, Charnes JM (eds) Proceedings of the 2002 winter simulation conference. Institute of Electrical and Electronics Engineers Inc., Piscataway, pp 79-84

Papakostas N, Papachatzakis P, Xanthakis V, Mourtzis D, Chryssolouris G (2010) An approach to operational aircraft maintenance planning. Decis Support Syst 48(4):604-612. doi:10.1016/ j.dss.2009.11.010

Sterman JD (2000) Business dynamics: systems thinking and modeling for a complex world. McGraw-Hill, Kingsport

Yuan J, Chaing J (2000) Optimal maintenance policy for a production system subject to aging and shocks. J Qual Maint Eng 6(3):200-216

Zineb S, Chadi S (2001) Maintenance integration in manufacturing systems: from the modeling tool to evaluation. Int J Flex Manuf Syst 13(3):267-285 (Springer Netherland) 